\title{
STUDI PANDANGAN DUNIA DALAM KARYA RABINDRANATH TAGORE, THE POST OFFICE
}

\author{
Dian Rahmani Putri \\ STMIK STIKOM Bali \\ rahmani@stikom-bali.ac.id |dira.putri78@gmail.com
}

\begin{abstract}
Abstrak
Penelitian ini mengambil pokok bahasan tentang pandangan dunia dalam karya Rabindranath Tagore (1861-1941), sebuah drama yang berjudul The Post Office yang pernah diterjemahkan ke dalam bahasa Indonesia oleh Moh. Yamin dengan judul Menantikan Surat Dari Raja. Adapun pendekatan yang dipakai dalam penelitian ini adalah sosiologi sastra dengan pendekatan strukturalisme genetik, yang pertama kali dikembangkan oleh Lucien Goldmann, seorang sosiolog berkebangsaan Perancis dalam tulisannya yang berjudul The Genetic Structuralists Method in the History of Literature. Tujuan khusus penelitian ini adalah untuk mengetahui sejauh mana pengaruh kehidupan pengarang dan kondisi sosial pada saat pengarang tersebut hidup terhadap karya sastra yang ditulisnya. Sementara tujuan jangka panjang penelitian ini adalah untuk menggali kekayaan nilai-nilai serta pesan kemanusiaan yang terkandung $\mathrm{d} i$ dalam berbagai karya sastra di dunia yang dapat memberikan inspirasi dalam kehidupan kepada masyarakat luas khususnya kepada pembaca karya sastra. Target penelitian ini adalah dapat menginspirasi pembaca untuk mencintai karya sastra yang dapat memberikan warna istimewa serta kesegaran dalam hidup dan kehidupan.
\end{abstract}

Kata kunci: world vision, sosiologi sastra, strukturalisme genetik, drama

\begin{abstract}
This study focuses on the world vision of Rabindranath Tagore (1861-1941) in the drama The Post Office; it has been translated into Bahasa Indonesia by Moh. Yamin, Menantikan Surat Dari Raja. The approaches used in this study are sociology of literature based on genetic structuralism, a theory founded and developed by the French sociologist Lucien Goldman in The Genetic Structuralists Method in the History of Literature. The specific purpose of this study is to examine in how far the author's life and social condition have influenced his work. Furthermore, the long-term purpose of this study is to gain knowledge of the richness of messages to humanity and their values as represented in world literature which affects its readers. The target of this study is to induce readers to love and enjoy literary works which color and enrich their lives.
\end{abstract}

Keywords: world vision, sociology of literature, genetic structuralism, drama

\section{PENDAHULUAN}

Manusia menuangkan gagasannya melalui karya. Pada mulanya manusia menciptakan sesuatu untuk memenuhi kebutuhan hidupnya, dan kemudian berkembang hingga ke arah tujuan aktualisasi diri. Mereka menciptakan peradaban dan juga kebudayaan yang dalam hal ini seni menjadi bagian di dalamnya karena adanya kreativitas dalam diri mereka. Dalam seni berkembang lukisan, tarian, musik dan kesusasteraan. Seni adalah sebuah kreativitas yang berdasarkan nalar yakni suatu hal yang paling istimewa yang dimiliki oleh manusia. Nalar ini yang menjadikan manusia sebagai mahluk termulia dari semua ciptaan yang ada.

Kesusateraan adalah suatu aktivitas kreatif dan juga sebuah karya seni. Di sisi lain, studi tentang kesusasteraan merupakan bagian dari ilmu pengetahuan. Studi kesusasteraan itu sendiri terbagi menjadi tiga: teori, kritik dan sejarah. Di dalam menilai sebuah karya sastra, seorang kritikus sastra harus memahami berbagai teori 
kesusasteraan dan menjadi seorang sejarawan sastra hendaknya lebih kritis sekalipun untuk tujuan menjadi sejarawan, demikian disampaikan oleh Norman Foerster (dalam Wellek dan Warren, 1989; 46).

Drama sebagai salah satu dari sejumlah jenis karya sastra dikenal sebagai presentasi dari kehidupan dan karakter yang tergambarkan melalui tindakan dan percakapan. Drama menghibur dan memberikan gagasan yang menginspirasi pembaca atau penontonnya, terlebih bahkan dapat mencetuskan untuk bertindak sesuatu. Sebuah drama ditulis untuk menyatakan isi pikiran (pesan) dari penulisnya. Dan untuk menggambarkan situasi sosial yang merupakan pengalaman kehidupan penulisnya. Tagore menyatakan bahwa karya sastra bukan suatu persoalan ontologis melainkan pengamatan sehari-hari.

Rabindranath Tagore, seorang pemikir India, menulis drama sejak usia 20 tahun. Ia telah menulis lebih dari 40 drama selama hidupnya. Ia telah dinobatkan sebagai Father of Modern Indian Stagecraft, Svakiya Natyadarshan o Manchabhavana. Menurutnya, seni peran diklasifikasikan menjadi delapan kelompok, yang suatu ketika mengalami tumpang tindih, yakni musik, syair, puisi, simbol, prosa, komedi, karakter dan drama-tari. Tagore adalah salah satu dari ikon Penulis Timur.Ia telah menulis ribuan puisi, esai, drama, komposisi musik, cerita pendek dan novel selama hidupnya. Karyakaryanya ditulis dalam bahasa Bengali terlebih dahulu dan berulah kemudian diterjemahkan ke dalam bahasa Inggris baik oleh beberapa rekannya maupun diterjemahkan sendiri.

Tagore juga seorang pejuang melalui karya-karya di bidang seni dalam melawan imperialisme dan fasisme yang mendunia pada masa itu. Tidak hanya dalam karya saja, Tagore juga banyak memberikan kuliah, tampil dalam pentas seni dan juga konser musik bahkan Tagore juga membuat sistem pengajaran yang banyak digunakan di sekolah-sekolah di India. Dan yang terpenting untuk India, Tagore melawan penjajahan Kerajaan Inggris yang berkuasa pada masa itu. Berbagai pemikirannya tertuang di dalam begitu banyak tulisan.

Dalam penelitian ini, sebuah drama karya Tagore yang berjudul Dakghar (The Post Office) adalah pentas yang paling sukses ditampilkan bahkan di luar negeri sebelum dipentaskan di India. Drama ini ditulis pada tahun 1912 dan diterjemahkan ke dalam Bahasa Inggris pada tahun 1914 oleh Devavrata Mokerjee dan direvisi sedikit oleh Tagore sendiri. Di Indonesia, Muh. Yamin menerjemahkannya dengan judul Menantikan Surat Dari Raja. Terjemahan terbaru ke dalam Bahasa Indonesia dipublikasikan pada tahun 2003 oleh Bentang Budaya dengan judul Surat Dari Raja. Yeats (1936) berkomentar tentang drama ini demikian, "Di atas panggung, drama kecil ini menunjukkan bahwa drama itu diciptakan dan dinyatakan dengan sempurna kehadapan penonton suatu emosi tentang kelembutan dan kedamaian". Di tahun 1960an Thompson mengatakan bahwa The Post Office adalah satu favorit 
dari sejumah besar karya Tagore, baik di Barat maupun di India. Ditambahkannya lagi, drama ini tidak tergolong closet drama yakni untuk dibaca saja, melainkan menarik untuk dipentaskan juga.

Drama ini berkisah tentang seorang anak bernama Amal yang menderita sakit parah sehingga ia tidak diijinkan ke luar dari kamarnya. Demikianlah ia benar-benar dikurung dalam kamarnya; hanya sebuah jendela yang dibiarkan terbuka. Meskipun dikurung, khayalannya berkelana sangat jauh, ia menjadi seolah-olah mengetahui apa saja hingga setiap orang yang melewati jendelanya dan bercakap-cakap dengannya menjadi terkesan. Amal selalu bermimpi ingin berkelana, menjadi seperti seseorang yang pernah ia temui di depan jendelanya. Suatu hari penjaga malam menyampaikan kepada Amal tentang sebuah kantor pos yang telah dibangun oleh raja untuk mengirimkan surat kepada Amal. Tanpa keraguan, Amal mempercayai perkataan penjaga malam itu meskipun kepala penjaga mengolok-olok dia dengan mengatakan bahwa Raja akan mengunjungi anak kecil yang miskin, yang adalah Amal sendiri. Drama ini diakhiri dengan kematian Amal, anak itu, yang disimbolisasikan dengan kedatangan Sang Raja, yang dapat diinterpretasi sebagai kedatangan Tuhan. Berdasarkan ringkasan cerita ini dapat dicermati bahwa ada sejumlah pesan dan nilainilai yang tersirat di dalam drama tersebut sehingga drama ini menarik untuk dieksplorasi lebih jauh.

Tagore sendiri dibesarkan di dalam keluarga yang istimewa dan juga memiliki pengalaman di lingkungan berbeda yang dinamis. Di antara orang-orang di sekitarnya Tagore termasuk orang yang istimewa. Gagasannya menakjubkan hingga bisa turut menggerakkan pertumbuhan dunia seni secara dinamis pada masa itu. Pada masanya, baik Timur maupun Barat melahirkan banyak penulis besar. Sebagai individu tentu saja Tagore memiliki pemikirannya tersendiri yang tertuang menjadi pesan-pesan di dalam karyanya. Tagore hidup di dalam kelompok sosial di mana ia menjadi salah seorang dari berbagai elemen pendukung yang penting dalam kesadaran kolektif, bahkan yang paling produktif menghasilkan pemikiran dan karya. Hidup dalam kelompok sosial tidak terlepas dari nilai-nilai yang merupakan konsep sosial tentang baik dan buruk atas suatu keadaan.

Studi ini adalah tentang telaah drama yakni karya Rabindranath Tagore yang berjudul The Post Office. Ada empat rumusan masalah yang menjabarkan tentang studi pandangan dunia pada penelitian ini yakni, pertama, bagaimanakah alur cerita yang merupakan salah satu unsur intrinsik dari drama ini? Kedua, bagaimanakah latar belakang sosial penulisnya dan sejauh mana kehidupan penulis mempengaruhi karyanya? Ketiga, adakah latar belakang sosial dan historis yang mengkondisikan masa drama itu ditulis? Keempat, amanat dan nilai-nilai apa sajakah yang terkandung dalam drama tersebut yang merefleksikan world vision atau pandangan dunia? 
Ada tiga aspek yang memformulasikan studi ini. Yang pertama, studi ini harus dimulai dari aspek intrinsik dari drama tersebut. Yang kedua, mengungkap latar belakang sosial penulisnya yakni kehidupan pribadi dan karya-karyanya. Dan yang terakhir adalah menemukan latar belakang kondisi sosial dan histori yang mempengaruhi penulis ketika menciptakan karya sastra tersebut. Dengan langkah-langkah tersebut, diperoleh pandangan dunia atau world vision penulis yang tercermin dari peran-peran yang terdapat di dalam drama tersebut yang tentu saja merupakan pemikiran dan nilai-nilai yang disampaikan oleh penulis karya tersebut.

Studi tentang pandangan dunia dalam kajian sastra dapat memberikan kontribusi dalam kajian sastra di mana sosilologi sastra dengan pendekatan strukturalisme genetik merupakan sebuah metode yang menarik untuk menelaah sebuah karya sastra. Studi pandangan dunia ini dapat dikembangkan untuk menemukan pesan dan nilai-nilai kemanusiaan yang terdapat di dalam sebuah karya sastra.

Metode yang digunakan dalam pengumpulan data adalah documentary research, yakni dengan menggali data dari berbagai pustaka acuan. Teknik yang digunakan adalah melakukan close reading terhadap drama The Post Office sebagai sumber data utama dengan tujuan untuk memperoleh pemahaman yang jelas, dan kemudian mengutip bagian-bagian penting dari drama tersebut yang penting untuk dikaji lebih mendalam dengan pendekatan strukturalisme genetik sosiologi sastra. Adapun metode yang dipakai dalam penelitian ini adalah metode sosiologi sastra dengan pendekatan strukturalisme genetik, yang pertama kali dikembangkan oleh Lucien Goldmann, seorang sosiolog berkebangsaan Perancis dalam tulisannya yang berjudul The Genetic Structuralists Method in the History of Literature. Teknik analisis yang digunakan berdasarkan alur berpikir induktif di mana data yang diperoleh dibahas satupersatu dengan lebih spesifik sehingga menemukan sebuah kesimpulan baik dengan generalisasi, analogi ataupun sebab akibat.

\section{KONSEP DAN KERANGKA TEORI KONSEP}

Konsep Sosiologi Sastra

Sapardi Djoko Darmono dalam Wahyuningtyas dan Santoso (2011:20) Sosiologiadalah ilmu pengetahuan yang mempelajari masyarakat dalam keseluruhannya bukansesuatu segi khusus masyarakat, terutama yang berhubungan dengan aspek-aspekmasyarakat yang menyangkut interaksi dan interelasi antarmanusia, syarat-syaratnya dan akibatakibatnya.

Sosiologi sastra sebagai ilmu objektif kategoris, membatasi diri pada apa yang terjadi dewasa ini bukan apa yang seharusnya terjadi. Terdapat dua kecenderungan utama dalam telaah sosiologi sastra yang antara lain adalah pendekatan yang berdasarkan pada anggapan bahwa sastra merupakan cer- 
min prosessosial ekonomi belaka dan pendekatan yang mengutamakan teks sastra sebagai bahan penelaahan yang kemudian dicari aspek-aspek sosial dari karya sastra.

\section{KERANGKA TEORI}

Menurut Goldmann (Endraswara 2003: 57) karya sastra sebagai struktur bermakna itu akan mewakili pandangan dunia pengarang, tidak sebagai individu melainkan sebagai anggota masyarakatnya. Sehingga karya sastra tidak akan dapat dipahami secara utuh jika totalitas kehidupan masyarakat yang telah melahirkan teks sastra diabaikan begitu saja. Pengabaian unsur masyarakat berarti penelitian sastra menjadi pincang. Strukturalisme Genetik merupakan embrio penelitian sastra dari aspek sosial yang kelak disebut sosiologi sastra. Hanya saja, Strukturalisme Genetik tetap mengedepankan juga aspek struktur. Baik struktur dalam maupun struktur luar, tetap dianggap penting bagi pemahamah karya sastra (Endraswara 2003: 60).

\section{PEMBAHASAN}

Berdasarkan pendekatan Strukturalisme Genetik, analisis dimulai dari pemahaman berbagai unsur intrinsik dari karya tersebut, dalam hal ini drama The Post Office. Analisis unsur instrinsik drama dibatasi pada plot/alur cerita. Ada beberapa tokoh penting dalam drama ini yaitu Amal sebagai tokoh utama, Madhav, Gaffer, Penjaga, Kepala Desa (antagonis), Pewarta Raja, Raja dan Sudha.
Analisis Unsur Intrinsik Drama: Plot/ Alur Cerita

Drama The Post Office terdiri dari dua actions; yang pertama terdiri dari lima scene, dan Action kedua terdiri dari sepuluh scene. Action 1 berlatarbelakang kejadian tersebut bertempat di rumah Madhav dan menjelaskan bagaimana Amal begitu dikasihi oleh Madhav, hingga ia menderita sakit; di sisi lain, pada Action 2 situasinya berubah, yakni di rumah Madhav sebelumnya dan kemudian kembali lagi ke rumah Madhav, meskipun demikian seluruh kejadian secara spesifik bertempat di tempat tidur Amal, dengan berbagai kejadian yang terkait menurunnya kondisi kesehatan fisik Amal sampai pada kematiannya. Tipe plot atau alur cerita drama ini adalah linear sebab alur drama ini dimulai dari awal cerita sampai akhir cerita meskipun ada sedikit flashback pada scene 2, Action 1. Alur cerita terdiri dari: pengenalan cerita, konflik atau pergerakan cerita, puncak konflik atau klimaks cerita, penyelesaian atau akhir cerita.

Pendahuluan cerita dijelaskan pada $A c$ tion 1, scene 2, yakni dialog antara Madhav dan Gaffer, yang menjelaskan bahwa seorang laki-laki yang bernama Madhav itu tidak memiliki anak. Ia adalah seorang pekerja keras, hidupnya terasa kering tanpa kehadiran anak. Ia sangat ingin mengangkat anak sampai akhirnya hadir seorang anak di kehidupan mereka. Anak itu diangkat dari anak saudara laki-laki istrinya. Anak itu telah yatim-piatu saat itu di mana ibunya meninggal saat ia masih bayi dan ayahnya 
menyusul kemudian. Anak itu membuat kehidupan mereka bahagia meskipun mereka harus merawat anak itu dan dan menghabiskan banyak uang untuk membesarkannya. Pengorbanan mereka terhadap anak itu tidaklah sia-sia dan itu menjadi kegembiraan yang nyata bagi mereka.

Konflik atau pergerakan cerita terdiri atas beberapa tahapan yang diawali dari $A c$ tion 1 scene 1, yakni dialog antara Madhav dan dokter, di mana dijelaskan bahwa kondisi anak tersebut kian menurun sehingga ia tidak diperbolehkan berada di luar ruangan. Dokter menjelaskan bahwa anak itu sakit dan sedang sekarat; tentu saja hal ini membuat Madhav gila. Ia sangat khawatir akan kehilangan anak satu-satunya yang dikasihinya, yang begitu kuat menghadapi sakit yang dideritanya. Ia berdebat dengan dokter tersebut dan mendesak dokter itu untuk segera menyembuhkan anaknya dengan cara alternatif, tetapi dokter tersebut membicarakan tentang takdir dan menyarankan agar anak itu tetap tinggal di dalam rumah dan meminum obat-obatan yang diberikan.

Konflik kedua terdapat pada Action 1 lanjutan scene 2, yakni di antara Madhav dan Gaffer. Madhav sangat khawatir kalau Gaffer mengajak anak itu bermain di luar rumah dan meminta bantuan untuk melakukan sesuatu yang membuatnya tetap tinggal di dalam kamarnya. Gaffer berjanji untuk membuatkan beberapa permainan yang membuatnya betah tinggal di dalam kamarnya. Ketika pulang dari bekerja, ia menemui anak itu dan di bagian drama ini ia dalam penyamaran.

Kisah semakin bergerak dinamis dalam tahap ketiga pergerakan cerita, di mana terjadi konflik di antara Madhav dan anaknya, Amal. Pada bagian ini diketahui bahwa anak laki-laki Madhav yang bernama Amal - terlepas dari sakitnya, ia adalah seorang anak yang aktif, penuh keingintahuan dan cerdas. Meskipun Amal tidak menolak untuk tinggal di dalam kamarnya, ia memohon pada ayahnya untuk diijinkan berbincang-bincang dengan orang-orang asing di luar dengan memanggil dari jendela kamarnya. Amal menyampaikan kepada ayahnya bahwa ia tidak mau menjadi orang yang terpelajar melainkan ia ingin menjadi seorang pengembara. Ia ingin pergi berkeliling dunia dan bersahabat dengan alam, ia lebih suka belajar dengan mengamati alam secara langsung. Sayangnya, ayahnya memiliki harapan yang berbeda.

Amal senang berbicara dengan orangorang yang melintas di depan jendelanya dan ia selalu membuat mereka terkagumkagum oleh kecerdasannya. Demikianlah sepanjang hari Amal berdiam di dekat jendelanya dan memanggil setiap orang yang lewat; salah satunya adalah Penjaga yang mengatakan kepadanya bahwa Raja telah membangun sebuah kantor pos baru dan barangkali Raja akan menulis surat untuknya suatu hari nanti. Hal itu telah membuat Amal bersemangat dan jiwa petualangnya bangkit hingga melambungkan anganangannya untuk menjadi seorang tukang pos suruhan Raja. Pada tahap keempat ini, ada 
pertentangan di dalam batin anak laki-laki itu. Ia ragu bahwa Raja dapat menghargai seorang anak kecil seperti dirinya. Selama hari-hari ia duduk di depan jendelanya, Amal juga bertemu Kepala Desa, Sudha, anak perempuan dari seorang penjual bunga, dan sekelompok anak-anak, namun hanya Kepala Desa yang memperlakukan Amal dengan buruk. Ia adalah seorang yang kasar dan perkataannya sinis ketika berbicara dengan Amal. Konflik muncul di antara Amal dan Kepala Desa karena persoalannya bukan saja mengenai Amal melainkan juga telah terjadi persoalan di antara Kepala Desa dengan Madhav, ayah Amal.

Pada Action 2 scene 6 terjadi dialog di antara Kepala Desa, Madhav, Amal dan Gaffer, yang membawa konflik hampir sampai pada klimaks cerita. Lagi-lagi terjadi konflik di antara Kepala Desa dengan mereka bertiga; kepala desa bertindak sangat kasar, ia menghina Amal karena nasibnya sehingga Raja akan mengirimkan surat untuknya. Meskipun demikian, Amal sangat baik kepada Kepala Desa tersebut dan ia tetap mempercayai surat tersebut dan bahwa Raja akan mengunjungi dia. Konflik tersebut memanas dengan kemarahan. Kesalahpahaman Kepala Desa oleh keangkuhannya dan kemarahan Madhav's yang melindungi anak yang dikasihinya telah menimbulkan pertentangan. Situasi semakin menegang pada scene 7, Action 2 yang menyatakan bahwa ada suara dari luar rumah Madhav, sesungguhnya itu suara Pewarta Raja, yang telah dibalas dengan teriakan oleh Kepala
Desa dengan suara dari mulut besarnya. Klimaks cerita ini terjadi dalam scene $8 \mathrm{Ac}$ tion 2, yakni mengenai kedatangan Raja untuk Amal; ia mengirimkan tabib kerajaan terlebih dahulu. Kepala Desa amat terkejut oleh kejadian ini. kejadian yang menginterupsi segalanya, yakni pengumuman kedatangan Raja yang dimulai dengan kedatangan Tabib Raja untuk memeriksa anak itu. Situasi semakin tragis saat Kepala Desa berseru, "My God!" - hal ini menjadi titik kesadaran Kepala Desa itu; bahwa akhirnya ia menyadari selama ini ia sungguh bersalah. Penyelesaian atau akhir cerita drama ini digambarkan dalam dua scene terakhir pada Action 2, yakni tentang pembebasan anak tersebut; kematian Amal yang penuh berkat. Sesaat sebelum kematiannya, ia terbebas dari rasa sakit dan rasa takut. Amal, anak itu, ia telah berangkat menuju Kantor Pos kepunyaan Raja.

\section{Latar Belakang Kehidupan Sosial Rabindranat Tagore}

Bagian ini menjelaskan tentang unsur luar dari drama The Post Office khususnya latar belakang kehidupan sosial atau biografi penulisnya yakni, Rabindranath Tagore. Pemaparan dibagi menjadi tiga bagian: keluarga Tagore, kehidupan Rabindranath Tagore dan karya-karya Rabindranath Tagore.

\section{Keluarga Tagore}

Tagore adalah nama yang berasal dari bahasa Bengali, Thakur, nama sebuah 
keluarga yang terkenal di Bengali modern. Mereka adalah keturunan brahmin yang telah berpenampilan sangat toleran dan memiliki hubungan yang dekat dengan kalangan nonbrahmin dan non-Hindu. Mereka telah dianggap turun kasta dan dikelompokkan dengan Pirali brahmin (nama bagi para Muslim pir atau orang suci kalangan Muslim pada masa itu). Keluarga Tagore adalah keluarga yang terkemuka, di antaranya Prasanakumar Tagore (1801-1868), Jotindramohan Tagore (1831-1907), Surindromohan Tagore (1840-1919); dan yang luar biasa adalah "Prince" Dwarkanath Tagore (1795-1846) sabahat dari Rammohan Roy, yang telah menyumbangkan kekayaannya yang begitu berlimpah untuk gerakan kemanusiaan dan reformasi Hindu secara khusus untuk penghentian suttee, kebebasan pers dan pendidikan Hindu. Ia dua kali mengunjungi Inggris, di mana saat pertama kali ia bertemu dengan Ratu Victoria. Ia meninggal dan dimakamkan di London.

Putra dari Dwakarnath adalah seorang reformis sosial dan relijius yang terkenal, Devenranath Tagore (1818-1905). Ia dididik oleh John Locke, David Hume dan para filsuf Barat lainnya. Awalnya ia mengikuti kepercayaan Brahmo Samaj namun akhirnya ia mendirikan gerakan Theistik baru yang bernama: Sadharan Bramo Samaj, dan ia sendiri menjadi ketuanya. Setelah beberapa lama Devenranath ia meninggalkan Brahmo Samaj dan menetap di tempat yang disebut Santiniketan, "pondok damai". Tempat ini nantinya menjadi nama sebuah universitas yang terkenal di India yang didirikan oleh putranya, Rabindranath Tagore. Penerus Tagore selanjutnya adalah Abanindranath Tagore dan Gaganendranath Tagore, penggagas aliran baru dalam lukisan gaya India modern. Jyotirindranath Tagore, seorang musisi terkemuka dan Svarnakumari Devi Tagore, seorang novelis wanita pertama di India. Dan di antara semuanya yang paling terkenal adalah Rabindranath Tagore, seorang penyair India, edukator dan filsuf yang telah memenangkan Nobel Prize.

\section{Kisah Hidup Rabindranath Tagore}

Rabindranath Tagore adalah anak keempat belas, lahir 7 Mei 1861. Ketika kecil, ia diasuh oleh seorang pelayan yang kasar dan pemalas, yang telah memperlakukannya dengan buruk. Ibunya meninggal ketika ia berumur empat belas tahun. Tagore kecil sering dikurung di dalam kamarnya; di kala ia rindu dunia luar, ia berjalan menuju jendela dan berimajinasi begitu luasnya sampai hal itu membuatnya memiliki rasa kasih sayang yang kuat terhadap alam di sepanjang hidupnya. Berikut ini penjelasan yang diperoleh dari pembukaan teks terjemahan tulisan Tagore yakni Nationalism oleh Tatang Sastradiwiria, yang sepintas mengulas masa kecil Tagore seperti tertuang di dalam My Reminiscences:

Rasa cinta Tagore yang luar biasa terhadap alam itu untuk sebagian besar dapat dicari sebab-sebabnya di masa ia kecil, ialah, sebagai kompensasi dari apa yang dideritanya di waktu itu. 
Ketika ia belum sekolah, bukanlah ibunya yang mengemong ia, tapi orang lain, seorang pengemong lakilaki yang samasekali tidak bertanggung jawab, lagi sangat kejam sifatnya dan pemalas luar biasa daalam menjalankan kewajibannya. Tiada segan-segan ia menutup Tagore seorang diri dalam sebuah kamar, dan dikuncinya kamar itu dari luar, agar ia dapat menjalankan sesuatunya, bebas dari kewajibannya menjaga dan mengamat-amati asuhannya. Maka dengan air mata yang berlinanglinang duduklah Tagore kecil di muka jendela, melihat tamasya indah yang melambai-lambai dari luar. Segala sesuatunya yang terlihat di kebun tiada lepas dari perhatiannya pohonpohonan dengan embun pagi berlinang -linang pada daaunnya, kolam kecil dengan air jernihnya yang melesit, binatang dan burung-burung yang beterbangan kian kemari. Jika seekor burung meloncat-loncat dari suatu daahan ke dahan lain, atau terus terbang ke udara menuju angkasa hijau, terdengarlah olehnya bunyi sayapnya mengepak-ngepak di hari pagi, merdeka...merdeka... demikianlah bunyinya. Juga angsa, bebek dan ayam yang berkeliaran di halaman mencari makanan kian kemari diiringi anakanaknya, semuanya bersuara, melagukaan lagu yang satu...merdeka...merdeka... Wahai, beta- pa besar bedanya keadaan mereka dengan keadaanya yang dikurung di dalam kamar? Taufan badai bergemuruh dalam dadanya, mengamuk, memberontak, hendak menghancurkan rantai-rantai yang membelenggu dirinya. Keinginan akan kemerdekaan dengan segala kehebatannya tumbuhlah dalam kalbu, merdeka dan berdekatan dengan alam. (1949; 7-8)

Itulah mengapa ketika ayahnya mengetahui keinginan anaknya, ia sering membawa Tagore untuk mengalami sendiri dan merasakan bagaimana kehidupan itu sesungguhnya. Beberapa kali ia dibawa ke Santhi Niketan di daerah pegunungan Himalaya, tempat ayahnya menyepi. Itulah waktu bagi Tagore kecil untuk mengenal alam lebih dekat disamping menerima banyak pengajaran dari sejumlah guru privat yang diundang ke rumahnya. Hal yang terpenting pada waktu itu adalah ia menerima pengajaran Upanishad oleh ayahnya sendiri hingga hal itu meningkatkan kecintaannya kepada alam, bahkan ketika ibunya meninggal dunia, ia menjadi lebih mencintai alam. Pada karyanya berikut ini Tagore mengungkapkan kekagumannya terhadap alam:

"Saya hidup di dalam kesunyian dan hal ini hari-datang yang terutama dari masa kecil saya. Bapak saya sangat jarang saya lihat, hampir selamanya ia keluar, tetapi jiwanya memenuhi seluruh rumah dan memberikan pengaruh sedalam-dalamnya kepada 
kehidupan saya. Sejak mula kecil saya, dapatlah saya mengenangkan, bahwa saya dengan gairah suka kepada alam. $O$, selalu saya menjadi gila karena kesenangan, jika saya melihat awan di langit naik gumpal demi gumpal. Saya insyaf bahwa saya dikelilingi oleh persahabatan sangat halus dan mesra, meskipun saya tak tahu bagaimana harus menamai keadaan itu. Saya menaruh cinta yang amat sangat kepada alam, hingga tak dapat rasanya saya menggambarkan dia. Alam itu ialah semacam sahabat yang penuh kasih sayang, yang selalu bersamasama dengan saya dan selalu menunjukkan keindahan baru." (Tamoe, 1948; 7)

Saat ia mencapai umur sepuluh tahun Tagore telah menunjukkan bakatnya dalam sastra. Ia membaca puisi untuk pertama kalinya pada umur empat belas tahun pada Cultural and Nationalism Festival di Bengal. Melihat bakat ini saudara laki-lakinya, Satyendranath Tagore mengirimnya bersekolah di London untuk belajar Sastra dan Hukum ketika ia berusia enam belas tahun. Ia belajar dengan cepat dan langsung kembali melanjutkan menulis puisi-puisi Bengali. Pada umur delapan belas tahun ia mulai dikenal masyarakat khususnya syairnya Sandhya Sangeet (1882).

Pada tahun 1890, ayahnya meminta Tagore untuk menjadi manajer warisan keluarga. Kemudian ia pindah ke tepi sungai
Gangga dan tinggal di sebuah kapal. Ia bersosialisasi dengan masyarakat di sana yang hampir semuanya sebagai petani dan masyarakat kelas bawah. Observasinya terhadap lingkungan ini telah memberikan inspirasi bagi karya-karyanya secara khusus dalam puisi dan cerita pendek. Pada periode ini, ia semakin bersimpati kepada orangorang miskin dan telah membangun begitu banyak proyek untuk para penduduk desa di sana.

Setelah tujuh belas tahun hidup di desa tersebut, ia memulai hidupnya sebagai seorang Sanyas, seorang guru, di tepi Sungai Padma. Di tempat itu, jiwanya terpanggil dari hari ke hari menuju kepada kesadaran bahwa ia harus menggali dalam-dalam warisan leluhurnya untuk dilestarikan dan disebarluaskan sebagai hadiah India bagi dunia. Tagore menyadari bahwa hidupnya haruslah berjalan dengan harmonis. Ia menolak kehidupan asketis yang mengabaikan dunia (The Gardener, 1936, hal. 119).

Pada tahun 1901, Tagore membangun sekolah yang bernama Santhi Niketan, tempat yang dahulu adalah tempat pertapaan ayahnya. Di tahun pertama ia hanya mempunyai lima orang murid, tetapi oleh kerja keras dan ketekunannya, ia mempunyai seratus lima puluh murid pada tahun kedua. Sekolah ini mengusung pola kehidupan sederhana yang bermakna kedekatan dengan alam dan kemerdekaan berpikir. Dalam kaitannya dengan determinasi alam, Tagore mengatakan janganlah membawa pohon ke dalam kelas melainkan bawalah kelasnya di 
bawah pohon. Pernyataan ini bermakna bahwa Tagore tidak mengharapkan para muridnya mempelajari ilmu pengetahuan seperti di dalam buku yang membosankan, ilmu yang tidak berasal dari akarnya sendiri. Ia sangat memperhatikan pendidikan spiritual. Yang dimaksud bukanlah agama yang sistematis, sebaliknya ia berpikir bahwa agama sesungguhnya bukanlah terdiri dari sistem agama faktual melainkan sebuah perasaan akan keberadaan Tuhan dengan alami. Anak -anak mengetahui Tuhan dengan sendirinya dengan lingkungan yang mengenal dan mengasihi Tuhan. sistem pendidikan yang dijalankan Tagore, adalah Ashram yang mengajari para murid untuk mencintai kebenaran lebih daripada harta kekayaan, mencintai alam dan saling menghormati semua ciptaan. (My School, 1970; 34-35).

Sekolah itu terus berkembang hingga tahun 1922 berkembang menjadi Universitas Vishva Bharati. Motto perguruan tinggi ini adalah Yatra Visvam Bharati Edanidam yang artinya, seluruh dunia menjadi satu di satu tempat. Pendidikan yang dilaksanakan menitikberatkan pada budaya yang mengacu kepada pembangunan mentalitas manusia.

Pada tahun 1913, Tagore dianugerahi Nobel Prize untuk karyanya Gitanjali (Song of Offerings). Ia adalah orang pertama Asia yang memenangkan penghargaan tersebut. Syair tersebut merefleksikan paradigma dan sikap hidup orang Timur terhadap hidup dan kehidupannya, disamping rasa kerinduan terhadap Sang Pencipta Agung. Pada tahun 1914, The University of Oxford menganuge- rahi Tagore gelar Doctor Honoris Causa di bidang Sastra. Perayaan penganugerahan ini dilaksanakan dengan menggunakan bahasa Latin dan pada kesempatan itu Doktor Tagore menyampaikan pidatonya dalam bahasa Sanskerta, bahasa kuno India. Tahun berikutnya, University of Calcuta juga mengaugerahkan penghargaan yang sama di bidang Sastra. Pada tahun 1913, Kerajaan Inggris melantik Tagore sebagai Knight (Satria) tetapi enam tahun kemudian ia mengundurkan diri dari kedudukan tersebut sebagai wujud protes atas pembantaian orang-orang India yang berdemonstrasi melawan rezim Inggris di Amritsar.

Tagore juga terlibat dalam pergerakan sosial India yang menentang imperialisme, dalam hal ini, rezim Inggris di India, serta menentang fasisme dan totaliterianisme di dunia. Dalam usianya yang ke 80 , ia menggambarkan masa depan dari semua penghancuran ini, dalam pidatonya yang berjudul Crisis in Civilization (2002: 726).

Rabindranath Tagore meninggal pada 7 Agustus 1941 ketika Perang Dunia II pecah. Lama sebelum hari wafatnya, ia telah menulis kata-kata perpisahan kepada dunia, berikut ini:

I have got my leave. Bid me farewell, my brothers! I bow to you all and take my departure.

Here I give back the keys of my doors - and I give up all claims to my house. I only ask for last kind words from you.

We were neighbors for long, but I re- 
ceived more than I could give. Now the day has dawned and the lamp that lit my dark corner is out. A summons has come and I am ready for my journey. (Gitanjali: XCIII)

\section{Karya-Karya Rabindranath Tagore}

Tagore mulai menunjukkan bakatnya di bidang Sastra ketika ia berusia sepuluh tahun. Karyanya mulai dikenal luas saat menulis Sandhya-Sangeet, Kidung Malam (1882) dan Prabhat-Sangeet, Kidung Pagi (1883). Ia telah menulis sekitar tiga ribu puisi dan sebagian besar puisi itu dibuat dengan aransemen musiknya. Karya besarnya dalam puisi, Gitanjali, Songs of Offerings, yang telah memenangkan Nobel Prize. Tagore mendapat hadiah 8000 pounsterling dan semua uang itu digunakan untuk mengembangkan sekolahnya. Ghose, seorang guru di Santhi Niketan mengatakan bahwa puisipuisi Tagore sangat luas, beragam, dan bervolume hingga melampaui skematisasi dan pengkategorian yang ada bahkan jika ingin menemukan sebuah pola yang belum pernah ada (1994: 32). Ia menulis sepanjang hidupnya, puisi terakhir yang ditulisnya berjudul Wings of Death (1941) yang telah diterjemahkan oleh Aurobindo Bose pada tahun 1960.

Karya novelnya tidaklah terkenal seperti beberapa novelis India lainnya. Bhabani Bhattaracharya, Atase Pers di Kedutaan Besar India di Washington mengatakan bahwa begitu luar biasa sang penyair juga menulis novel-novel yang bagus (1992: 96). Novel karya Tagore di antaranya: Choker Bali (Eyeshore, 1902), Sesher Kavita (Farewell My Friends, 1949), Char Adhyay (Four Chapters, 1950), Ghare-baire (The Home and the World, 1919), dll. Karya novel terbesarnya adalah Gora (1909), novel ini sungguh merupakan ekspresi diri yang nyata menolak imperialism, menghormati kesetaraan, dan terlebih dari semuanya, menggambarkan dirinya sebagai seorang kosmopolitan. Tagore juga menulis beberapa cerita pendek seperti Parrot's Training, 'Didi' (kakak perempuan), dan yang istimewa, 'The Hungry Stones' dan 'Kabuliwallah' di mana sebuah kritik telah mengklasifikasikan karya ini menjadi empat kategori: cinta, hubungan sosial, hubungan antara manusia dengan Alam dan supranatural.

Tagore juga menulis banyak esai, kuliah, khotbah dan teks pidato juga. Pemikiran besarnya dituangkan ke dalam tulisannya, Religion of Man dan Sadhana. Sekolah miliknya, Santhi Niketan (Abode of Peace) adalah salah satu dari karya besarnya; yang telah berkembang menjadi sebuah perguruan tinggi bernama Vishva Bharati. Ia telah berkunjung keliling dunia untuk menyebarkan gagasannya; dan juga pergerakannya melawan imperialism, totaliterianisme dn fasisme melalui pemikiran dan sikapnya. Pidato publik disampaikan empat bulan menjelang kematiannya, 'Crisis in Civilization' ia membandingkan dengan keras bagaimana pendidikan Inggris dilaksanakan di India dengan bagaimana Soviet 
melaksanakannya bagi orang-orang Rusia.

Rabindranath Tagore menulis lebih dari empat puluh drama. Beberapa dari karyanya Valmiki Pratibha (The Genius of Valmiki), karya pertama saat berusia sekitar dua puluh tahun, Nalini, Prakritir Pratisodh (Nature revenge), Raktakarabi (Red Oleanders), dll. Karya drama yang paling sukses adalah Dakghar (The Post Office). Ghose berkomentar bahwa drama ini adalah keseimbangan di antara realisme pedesaan dan sebuah simbolisme yang menggugah lintas wilayah, menusuk hati dengan rasa kesedihan dalam hal-hal yang fana. Yeats menitikberatkan perhatian pada strukturnya yang sempurna, kelembutannya dan sebuah situasi damai yang mendalam daripada sebuah tragedy, meskipun anak laki-laki itu sakit di tempat tidurnya, karya ini dibuat untuk menyatakan gagasan yang terlalu besar untuknya. Tetapi Tagore mempertahankan maksud dan metodenya dengan membandingkan tokoh pahlawan dalam drama dengan dirinya:

"I remember, at the time I wrote it, my own feeling... Amal represents the man whose soul has received the call of the open road."

Pernyataan ini tampaknya lebih dapat diterima sebagai rasionalisasi; semua pembaca Tagore atau orang-orang yang telah menonton pementasannya dapat memahami hal ini. Dilihat dari masa kecil Tagore, kita dapat menemukan bahwa bagian ini adalah rekonstruksi dari kisah hidupnya sendiri (baca subbab sebelumnya).

Sapardi Djoko Damono dalam Seminar Internasional Rabindranath Tagore di Denpasar menyatakan bahwa Tagore telah menulis seribu puisi, lebih dari dua lusin drama, delapan novel dan lebih dari delapan kumpulan cerita pendek, lebih dari dua ribu lagu-lagu dengan musik dan lirik yang diaransemen sendiri, sejumlah esai, yang meliputi berbagai bidang bahasan seperti: sastra, sosial, agama, dn politik, berbagai kuliah di banyak negara di Asia, Eropa dan Amerika, seorang educator, pembaharu agama dan sosial dan juga sebagai politisi (1998: 5). J.C. Gosh menyebut Tagore sebagai Titan, Orang Besar.

\section{Latar Belakang Sosia-Historis}

India adalah sebuah Negara yang masyarakatnya memiliki pluralistic dan multi-kultural di mana sistem kepercayaan mengatur kehidupan individual. India bukanlah sebuah Negara Hindu meskipun Hindu adalah agama terbesar yang di yakini oleh masyarakat di Negara tersebut. Ada banyak tradisi relijius; baik yang asli dan tradisi dari luar yang telah dilaksanakan selama bertahun-tahun. Ada ajaran Buddha, Sikh, kultus Bhakti, tradisi Sufi, dan juga Islam serta Kristen. Banyak guru-guru agama, pembuat peraturan, reformis sosial dan negarawan yang memberikan pengaruhnya bagi kehidupan dan budaya orang-orang India. Mahabharata, Bhagavat Gita, dan Upanishad serta Alquran dan Alkitab, Guru Bani, dll. Telah membentuk pola pikir dan 
kesadaran orang-orang India. Demikian juga sistem kasta Hindu dan pola rantai keluarga telah memberi pengaruh yang besar bagi para pengikut agama lainnya.

Pada tahun 1911-1912, India masih dalam jajahan Inggris. Namun demikian hal itu tidak menutup kreativitas Tagore; bahkan ia menjadi lebih produktif pada masa itu. Ia menulis dalam bahasa Bengali, Dakghar (drama), Galpa Chariti (kumpulan cerita), Jivansmriti (Kenang-Kenangan), Chinapatra (surat-surat) dan Achalayatan (drama) dan terjemahan dari Gitanjali oleh William Buttler Yeats.

Tagore juga telah menciptakan lagu nasional India yang terkenal, 'Jana-ganamana-adhinayaka' yang dinyanyikan untuk pertama kalinya pada bagian ke-26 dari Kongress Nasional India (27 Desember 1911) yang diselenggarakan di Kalkuta, lagu ini nantinya menjadi salah satu dari lagu kebangsaan India. Di tahun yang sama ia mulai menulis drama Dakghar dan selesai pada tahun berikutnya. Drama ini pertama kali dipentaskan di Irish Theatre, London, pada tahun 1913. Pementasan ini juga merupakan salah satu wujud aksi protes. Pada 13 April 1919 , terjadilah penembakan oleh polisi terhadap rakyat tidak bersenjata di Amritsar. Banyak yang terbunuh dan diperlakukan dengan keji. Kebebasan pers dibelenggu. Meskipun demikian Tagore tetap berjuang keras dalam aksi protesnya. Ia mengembalikan gelar kebangsawanan Inggris-nya kepada Viceroy. Meskipun di tengah keadaan negara yang menjelang kekacauan, pementa- san drama Dakghar (The Post Office) tetap dilaksanakan di Jorasanko Mansion, dihadiri oleh sejumlah tokoh India seperti: M.K. Gandhi, Mohan Malviya, Annie Besant, dll. Terlihat jelas bahwa Tagore menolak penghinaan dan melewati penghancuran yang telah dibuat oleh pemerintah Inggris; sikapnya adalah bahwa perlakuan kejam pemerintah Inggris tidak bisa menghentikan kreativitas India.

\section{Amanat/Pesan Tagore Dalam Drama The Post Office}

Di dalam drama The Post Office ini, Tagore mau menyampaikan pesan atau amanatnya dengan melibatkan dirinya ke dalam tokoh yang ada di dalamnya, yakni Amal. Pesan yang pertama adalah bahwa pendidikan tidak hanya diperoleh dengan membaca buku atau pendidikan formal yang dibatasi tembok-tembok kelas. Hal terpenting dalam pembelajaran adalah mengetahui dan mengalami semua fenomena kehidupan; pembelajaran dengan cara ini yang lebih manusiawi. Sebagaimana dinyatakan Tagore, 'do not bring trees into the class but bring the class under the tress.' Tubuh jasmani dapat dikurung, seperti tokoh Amal dalam cerita, namun pikiran tetap bebas. Pikiran dapat berkelana ke mana saja yang diinginkan pemiliknya.

Penulis ingin menyebarkan gagasannya dengan menggunakan tokoh seorang tukang pos, yang memberikan layanan komunikasi, yang memberikan informasi yang membuat orang mengetahui lebih jelas serta mem- 
berikan layanan sehingga orang dapat memahami satu sama lain melalui tulisantulisan mereka. Di sepanjang hidupnya Rabindranath Tagore menulis dan menciptakan karya seni dan sungguh, pemikirannya masih ada hingga sekarang.

\section{Nilai-Nilai yang Terkandung dalam Dra- ma The Post Office}

Ada beberapa action dalam drama yang merefleksikan nilai-nilai masyarakat India yang merupakan world vision. Nilai yang mau disampaikan yang pertama adalah tentang kesetaraan. Di beberapa bagian pada drama dilihat bahwa karakter Kepala Desa sangat buruk. Ia kerap kali merendahkan orang lain dan tingkah lakunya kasar. Adalah suatu kebiasaan di desa bahwa kepala desa memiliki otoritas namun juga ia adalah orang yang dipercaya, bukan orang yang harus dilayani saja. Tagore menggunakan pilihan kata dengan ungkapan hiperbolis, yang bertujuan untuk menyentuh sisi kemanusiaan dari pembacanya sehingga disadari bahwa manusia hidup bersama dalam sikap saling menghormati dan memiliki hak hidup yang sama di dalam masyarakat. Nilai yang kedua mempertimbangkan kembali tradisi yang sudah tidak sesuai dengan kehidupan aktual. Ketiga, karma, yakni jalan menuju pembebasan.

\section{SIMPULAN}

Amanat dan nilai dalam karyanya sebagaimana dijabarkan pada analisis secara universal dapat diterima. Pesan dan nilai da- lam karya mencerminkan kesadaran kolektif yang dapat diterima secara oleh masyarakat luas. Melalui biografinya, diketahui bahwa Rabindranath Tagore terlahir di keluarga yang istimewa dan terpandang di kalangan sosial di masa itu, serta menjadi orang yang paling istimewa di antara anggota keluarganya. Hal ini telah menginspirasi masyarakat India dan memberikan konstribusi yang terbentuk oleh gagasannya kepada dunia sebagaimana ia terinspirasi oleh Upanishad. Oleh tulisan dan kreativitas seninya, yang secara teknis, di dunia Barat, Rabindranath tidak terhapus melainkan karakteristik Timurnya masih tetap hidup dan mewarnai keseluruhan hidupnya. Rabindranath Tagore berhasil mentrasformasikan pemikirannya.

Amanat atau pesan yang terkandung pada drama The Post Office yang merefleksikan world vision dan juga fakta kemanusiaan secara umum bahwa semua manusia bebas dan berkedudukan setara sejak lahir, sehingga mereka pantas memperoleh pendidikan serta pengalaman yang seluas-luasnya. Pemikiran setiap manusia bebas dan seharusnya memiliki totalitas dalam berkarya sehingga manusia dapat merasakan kepuasan dalam hidupnya. Manusia hidup saling menghormati, memiliki rasa kasih dan menyebarluaskan pengetahuan dan karya mereka sehingga berguna baik bagi masyarakat maupun bagi alam.

Nilai yang terkandung dalam drama The Post Office adalah pertama mempertimbangkan kembali tradisi yang sudah tidak sesuai dengan kehidupan aktual. Yang 
kedua, karma, yakni jalan menuju pembebasan. Ketiga, kesetaraan di antara umat manusia. Semua nilai tersebut mencerminkan kesadaran kolektif yang telah bertumbuh pada masyarakat pada zaman itu, di mana dalam nilai tersebut tercermin ajaran Upanishad sebagai Weda 'baru'. Tagore sebagai penulis telah berhasil menuangkan kesadaran kolektif tersebut ke dalam karya sastra, yakni drama The Post Office. Tagore dalam karyanya adalah sebuah fakta kemanusiaan sebagai subjek kolektif maupun subjek individual yang merespon situasi dan kondisi zamannya.

Demikianlah studi world vision dalam drama The Post Office karya Rabindranath Tagore. Penelitian karya sastra sangat bermanfaat untuk membangun karakter dan rasa kemanusiaan sehingga tercipta keseimbangan antara kemajuan ilmu pengetahuan dan teknologi serta ilmu humaniora dalam kehidupan.

\section{UCAPAN TERIMA KASIH}

Penulis mengucapkan terima kasih kepada Mitra Bebestari atas masukanmasukan yang bermanfaat untuk perbaikan artikel ini.

\section{DAFTAR PUSTAKA}

Abrams, M. H. (1979). The Mirror and The Lamp. New York: Oxford University Press

Agastia, IBG, dkk. (2002). Puisi Sepanjang Masa. Denpasar: Yayasan Dharma Sastra

Bierstedt, Robert (1957). The Social Order, an Introduction to Sociology. New York: McGraw Hill Book Co. Inc.

Chakravarty, Amiya, Ed. (1966), A Tagore Reader. Boston: Beacon Press
Chari, S.M. Srinivasa. (2002), The Philosophy of the Upanisads, New Delhi: Munshiram Manoharlal Publisher Pvt. Ltd.

Damono, Sapardi Djoko. (1998). "Rabindranath Tagore, India dan Kita", Makalah Seminar Internasional Rabindranath Tagore 16 -17 Februari 1998

Das, Sisir Kumar, Ed., (2001) The English Writings of Rabindranath Tagore Vol. Two: Plays.Stories.Essays., New Delhi: Sahitya Akademi.

Das, Sisir Kumar, Ed., (2002) The English Writings of Rabindranath Tagore Vol. Three: A Miscellany, New Delhi: Sahitya Akademi

Echol, John M.,Shadily, Hasan.(1992). Kamus Inggris Indonesia.Jakarta: PT Gramedia

Echol, John M., Shadily, Hasan.(1994). Kamus Indonesia Inggris. Jakarta: PT Gramedia

Endraswara, Suwardi. (2004). Metodologi Penelitian Sastra.Yogyakarta: Pustaka Widyatama

Ghose, Sisirkumar. (1994). Makers of Indian Literature Rabindranath Tagore, New Delhi: Sahitya Akademi

Hornby, AS. (2000), Oxford Advanced Learner's Dictionary Sixth Edition. New York: Oxford University Press

Jabrobim, Ed. (2003). Metodologi Penelitian Sastra. Yogyakarta: PT Hanindita Graha Widya

Keeney, William. (1984). How to Analize Drama.New York: Monarch Press

Knickerbocker, K.L. (1960) Interpreting Literature. US: Holt, Rinehart and Winston, Inc.

Pfister, Manfred. (1993). The Theory and Analysis of Drama. UK: Cambridge University

Radhakrishnan, Dr., S., (1992) A Cetenary Volume 1861-1961, New Delhi: Sahitya Akademi

Saraswati, Ekarini, Dra., M.Pd. (2003). Sosiologi Sastra Sebuah Pemahaman Awal, Malang: Bayu Media \& UMM Press

Soemardjan, Selo, Prof. Dr., Soemardi, Soelaeman, SH., MA.(1964). Setangkai Bunga Sosiologi.Jakarta: Universitas Indonesia

Tagore, Rabindranath. (1936). Collected Poems and Plays of Rabindranath Tagore.London: Macmillan

Tagore, Rabindranath. (1945). My Boyhood Days. Calcutta: Vishva Bharati

Tagore, Rabindranath. (1948). Tamoe dan Beberapa Kisah Yang Lain. Jakarta: Balai Pustaka

Tagore, Rabindranath. (1949). Nasionalisme.Terj. Tatang Sastrawiria. Jakarta: Balai Pustaka

Tagore, Rabindranath. (1952). Gitanjali. Disalin oleh Amal Hamzah. Jakarta: Penerbit Ke- 
bangsaan Pustaka Rakjat

Tagore, Rabindranath. (1976). Tukang Kebun.Terj. Hartojo Andangdjaja. Jakarta: Penerbitan Khusus Budaya Jaya

Tagore, Rabindranath..(1988). Sadhana. Macmillan Pocket Tagore Edition. New Delhi: Macmillan India

Teeuw, Prof., Dr. A. (2003) Sastera dan Ilmu Sastera. Bandung: Pustaka Jaya

Thompson, Edward J., Dr. (1960). Rabindranath Tagore His Life and Work. Calcutta: Y.M.C.A. Publishing House

Walker, Benjamin. (1983). An Encyclopedic Survey of Hinduism: Hindu World Vol. II. New Delhi: Munshiram Manoharlal Publishers Pct., Ltd.

Waluyo, Herman J., Prof., Dr. (2001) Drama: Teori dan Pengajarannya. Yogyakarta: PT Hanindita Graha Widya

Webster, Merriam. (2003). Merriam-Webster's Collegiate Dictionary Eleventh Edition.Massachusetts: Merriam-Webster, Inc.

Wellek, Rene. Warren, Austin. (1956). Theory of Literature.New York: Harvest Book. 